\title{
Survey of saproxylophagous Melolonthidae (Coleoptera) and some biological aspects in Aquidauana, MS
}

\author{
Felix Placência Garcia ${ }^{1}$, Sérgio Roberto Rodrigues ${ }^{1,2}$, \\ Cristiane Aparecida Constante Bagnara ${ }^{1}$ \& Diogo Silva de Oliveira ${ }^{1}$ \\ ${ }^{1}$ Universidade Estadual de Mato Grosso do Sul-UEMS, CEP 79200-000, Aquidauana, MS, Brasil \\ ${ }^{2}$ Corresponding author: Sérgio Roberto Rodrigues, e-mail: sergio@uems.br
}

GARCIA, F.P., RODRIGUES, S.R., BAGNARA, C.A.C. \& OLIVEIRA, D.S. Survey of saproxylophagous Melolonthidae (Coleoptera) and some biological aspects in Aquidauana, MS. Biota Neotrop. 13(3): http:// www.biotaneotropica.org.br/v13n3/en/abstract?article+bn00813032013

\begin{abstract}
Coleoptera of the family Melolonthidae plays an important role in decomposition and nutrient recycling in the environment, however the information of this group is scarce in Brazil; therefore studies were developed with the objective of understanding the biological aspects of saproxylophagous. The studies were developed in the experimental farm of the State University of Mato Grosso do Sul, in Aquidauana, from March 2011 to April 2012. In a forest fragment of the cerrado, when encountering fallen tree trunks, they were cut into small pieces for extraction and acquisition of immature and adult Melolonthidae. Larvae were taken to the laboratory where they were reared until emergence of adults, obtaining biological and biometric data. A total of 145 larvae and 11 adults were collected. Third instar larvae of Strategus surinamensis Burmeister, 1847, collected in this phase lasted 230 days and 31.3 days in the pupal stage. Third instar larvae of Phileurus valgus (Linnaeus, 1758), in this phase lasted 49 days and 13 days in the pupal stage. Third instar larvae Pelidnota fulva Blanchard, 1850, after being collected remained for 61 days in this phase and 25.3 days in the pupal stage. Adults Pelidnota aff. vazdemelo were collected inside tree trunks. To Macraspis festiva Burmeister, 1844, the third instar larvae collected lasted for 39 days at this stage, and pupae lasted 17 days. Third instar larvae of Rutela lineola (Linnaeus, 1767), in this phase lasted 23 days, and pupae lasted 16.3 days. To Hoplopyga liturata (Olivier, 1789), third instar larvae collected lasted 21 days and pupae lasted 18 days. To Hoplopyga boliviensis (Moser, 1918), third instar larvae lasted 33 days and pupae 16 days. Second and third larval instar Marmarina maculosa (Olivier, 1789) collected lasted respectively, 105 and 171.3 days and pupae lasted 26 days. The species collected in greatest quantity were M. festiva with 75 larvae, R. lineola with 20 larvae and H. boliviensis with 18 larvae. Larvae were collected during several months, where in July 32 larvae were sampled and in August 39 larvae, the largest quantities encountered. Keywords: Cetoniinae, decomposers, Dynastinae, Rutelinae.
\end{abstract}

GARCIA, F.P., RODRIGUES, S.R., BAGNARA, C.A.C. \& OLIVEIRA, D.S. Levantamento de Melolonthidae (Coleoptera) saproxilófagos e alguns aspectos biológicos em Aquidauana, MS. Biota Neotrop. 13(3): http:// www.biotaneotropica.org.br/v13n3/pt/abstract?article+bn00813032013

Resumo: Os coleópteros da família Melolonthidae desempenham importante função na decomposição e reciclagem de nutrientes no meio ambiente, assim, foram desenvolvidos estudos com o objetivo de se conhecer as espécies saproxilófagas ocorrentes e os aspectos biológicos. Os estudos foram desenvolvidos na fazenda experimental da Universidade Estadual de Mato Grosso do Sul, em Aquidauana, de março de 2011 a abril de 2012. Em área de fragmento de mata de cerrado, troncos de árvores caídos, eram cortados em pequenas partes para realizar a extração e obtenção de imaturos e adultos. As larvas coletadas foram levadas para o laboratório para realizar a sua criação até a emergência dos adultos, sendo obtidos os dados biológicos e biométricos. Foram coletadas 145 larvas e 11 adultos. Larvas de terceiro instar de Strategus surinamensis Burmeister, 1847, coletadas duraram 230 dias nessa fase e 31,3 dias na fase de pupa. Larvas de terceiro instar de Phileurus valgus (Linnaeus, 1758) duraram 49 dias nessa fase e 13 dias na fase de pupa. Larvas de terceiro instar de Pelidnota fulva Blanchard, 1850, após serem coletadas permaneceram por 61 dias nessa fase e 25,3 dias na fase de pupa. Foram coletados adultos de Pelidnota aff. vazdemeloi dentro de troncos de árvores. Para Macraspis festiva Burmeister, 1844, as larvas de terceiro instar coletadas duraram por 39 dias nessa fase, e as pupas duraram 17 dias. Larvas de terceiro instar deRutela lineola (Linnaeus, 1767) duraram 23 dias nessa fase, e as pupas duraram 16,3 dias. Para Hoplopyga liturata (Olivier, 1789) as larvas de terceiro instar coletadas duraram 21 dias e as pupas duraram 18 dias. Para Hoplopyga boliviensis (Moser, 1918) larvas de terceiro instar duraram 33 dias e as pupas 16 dias. Larvas de segundo e terceiro instar de Marmarina maculosa (Olivier, 1789) coletadas, duraram respectivamente, 105 e 171,3 dias e as pupas duraram 26 dias. As espécies coletadas em maior quantidade foram $M$. festiva com 75 larvas, $R$. lineola com 20 larvas e $H$. boliviensis com 18 larvas. As larvas foram coletadas em vários meses, sendo que em julho amostrou-se 32 larvas e em agosto 39 larvas, sendo as maiores quantidades encontradas.

Palavras-chaves: Cetoniinae, decompositores, Dynastinae, Rutelinae. 


\section{Introduction}

The larvae of some Melolonthidae species develop and feed on dead tree trunks, thus assisting in the decomposition process, and this behavior plays an important role in the recycling of organic material in the environment. In Brazil, few studies have been conducted on Melolonthidae that feed on decaying wood, some informations are available about morphology and biology.

For some species of the subfamily Rutelinae occurring in Brazil are known for some information Macraspis, Pelidnota and Rutela. Vanin \& Costa (1980) studied biological and morphological aspects of immature Macraspis cincta (Drury, 1782) from larvae collected within decaying tree trunks in three locations in the state of São Paulo and one from the state of Santa Catarina, Brazil. Larvae, pupae and adults of Macraspis festiva Burmeister, 1844 and $M$. pseudochrysis Landin, 1956 were collected from rotting logs in the state of Amazonas, Brazil, by Morón \& Paucar-Cabrera (2003) who described its immature phases. The biology and morphology of the third instar larva Pelidnota fulva Blanchard, 1850 created in decaying material were studied by Rodrigues \& Falco (2011) and Rodrigues et al. (2012). From eucalyptus posts, several larvae of Rutela lineola (Linnaeus, 1767) were obtained by Link (1979) in Santa Maria, RS and reared in the laboratory.

In the subfamily Dynastinae, of some species occurring in Brazil were obtained some information. Larvae of Strategus surinamensis hirtus Sternberg, 1910 were found in dead tree trunks, and obtained information about its biological and morphological (Costa et al. 1988). Larvae of Trioplus cylindricus (Mannerheim, 1829) were obtained from fallen logs in an advanced state of decomposition in the city of São Paulo. From this material it was possible to describe the larva and pupa (Vanin et al. 1983).

In the subfamily Cetoniinae some species that occur in Brazil, can develop in decaying material. Therefore, larvae and adults of Hoplopyga brasiliensis (Gory and Percheron, 1833) collected in decaying wood, Vanin \& Costa (1984) described the immature species and found that larvae construct pupal chambers with the substrate particles where they develop. Costa et al. (1988) collected nine larvae of Inca bonplandi (Gyll., 1827) from the stem of a fallen palm tree in an advanced state of decomposition. In the laboratory they reared the larvae to obtain pupae and adults, then, the immature phases were described.

Due the importance of Melolonthidae species in recycling plant and wood material in different environments, studies were conducted to know this fauna. Also it was possible study some biological aspects of species which live in dead wood in a forest fragment of the cerrado, between the Pantanal and Cerrado biomes in Aquidauana, MS, Brazil.

\section{Material and Methods}

The studies were developed in an experimental farm of the Universidade Estadual de Mato Grosso do Sul (UEMS), in the municipality of Aquidauana, MS. The UEMS experimental farm is located between the Cerrado and Pantanal biomes, and has an approximate area of 800 hectares. This area consisted of 200 hectares of a dense forest fragment, which was used to sample the saprophagous Melolonthidae species, from March 2011 to April 2012. The local average altitude is 149 meters, the average annual temperature is $26^{\circ} \mathrm{C}$ and average annual rainfall is from 1200 to $1500 \mathrm{~mm}$.

On dead tree trunks or branches, either fallen or standing, sampling was performed every 15 days, removing the insects. For this purpose, logs encountered in the field were cut for their fractionation and to enable the extraction of larvae and adults from their interior (Figure 1). On average five trunks were evaluated by sampling, and

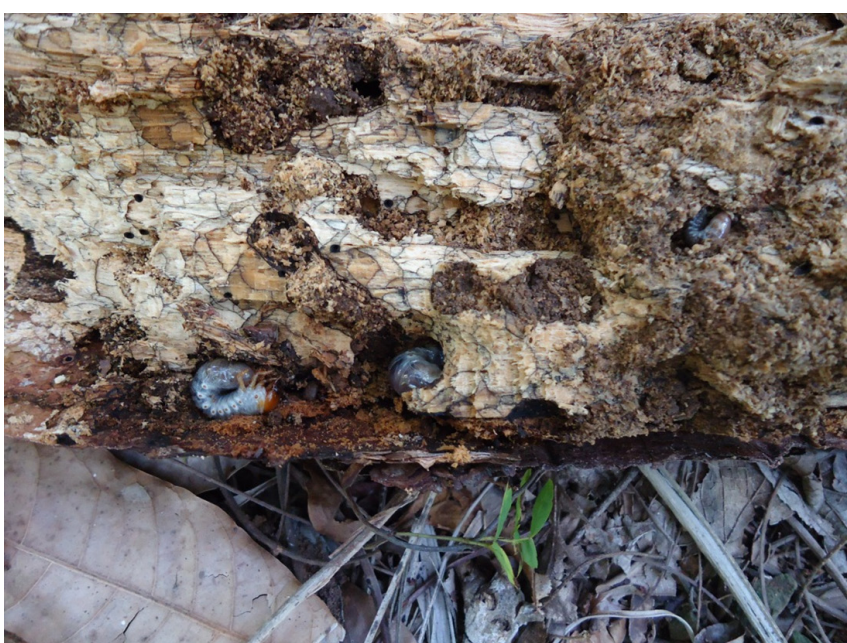

Figure 1. Larvae of Scarabaeidae sampled in logs, in Aquidauana, MS, from March 2011 to April 2012.

larvae were taken to the laboratory where they were measured and reared until emergence of adults.

Larvae were measured with a caliper, assessing the width of the head capsule, and width and length of the body. After the measurements, they were individualized in $500 \mathrm{~mL}$ plastic bottles, filled with decaying wood to serve as a food source, and remained in this location until the emergence of adults. The larvae were measured weekly to monitor their development (Rodrigues \& Falco 2011).

The adults obtained were mounted with entomological pins and preserved in the entomological collection of the UEMS. The specimens were identified by Dr. Sérgio Ide (Instituto Biológico de São Paulo, Brazil), Dr. Fernando Zagury Vaz-de-Mello (Universidade Federal de Mato Grosso, Brazil), and some species were identified by comparison with specimens deposited in the collection of the UEMS. Specimens were then deposited in the entomology collection of the UEMS, in the Instituto Biológico de São Paulo and in the Universidade Federal do Mato Grosso.

\section{Results}

A total of 145 larvae and 11 adults of Melolonthidae were collected (Tables 1,2). Of the adults collected and larvae reared in the laboratory, species were identified as being from the subfamilies Dynastinae, Rutelinae and Cetoniinae. The following species were collected Strategus surinamensis Burmeister, 1847 and Phileurus valgus (Linnaeus, 1758) (Dynastinae); Pelidnota fulva Blanchard, 1850, Pelidnota aff. vazdemeloi, Macraspis festiva Burmeister, 1844 and Rutela lineola (Linnaeus, 1767) (Rutelinae); and Hoplopyga liturata (Olivier, 1789), Hoplopyga boliviensis Moser, 1918 and Marmarina maculosa (Olivier, 1789) (Cetoniinae).

The largest quantities of larvae were obtained for M. festiva with 75 , R. lineola with 20 and H. boliviensis with 18 larvae sampled. The months with the largest quantity of larvae sampled were July with 31 and August with 39 larvae (Table 1).

Some biological and biometric aspects of the species were obtained, which are presented below.

\section{Dynastinae}

\section{Strategus surinamensis}

Nine third instar larvae were obtained, three in May 2011, four in March 2012 and two in April 2012 (Table 1). The third instar larvae collected in 2012 completed their life cycle in the laboratory to reach 
Garcia, F.P et al.

Table 1. Larvae of "saproxylophagous Melolonthidae sampled in a forest area in Aquidauana, MS, from March 2011 to April 2012.

\begin{tabular}{|c|c|c|c|c|c|c|c|c|c|c|c|c|c|c|c|}
\hline Subfamily/Species & Mar & Apr & May & June & July & Aug & Sept & Oct & Nov & Dec & Jan & Feb & Mar & Apr & Total \\
\hline \multicolumn{16}{|l|}{ Dynastinae } \\
\hline Strategus surinamensis & & & 3 & & & & & & & & & & 4 & 2 & 9 \\
\hline Phileurus valgus & & 4 & & & & & & & & & & & & 5 & 9 \\
\hline \multicolumn{16}{|l|}{ Rutelinae } \\
\hline Pelidnota fulva & & & & 5 & 1 & & & & & & & & & & 6 \\
\hline Macraspis festiva & & & & & & 39 & & & & & 17 & 4 & 12 & 3 & 75 \\
\hline Rutela lineola & & & & & 20 & & & & & & & & & & 20 \\
\hline \multicolumn{16}{|l|}{ Cetoniinae } \\
\hline Hoplopyga boliviensis & & & & & 9 & & 9 & & & & & & & & 18 \\
\hline Hoplopyga liturata & & & & & 2 & & & & & & & & & & 2 \\
\hline Marmarina maculosa & & & & & & & & & & & & & 6 & & 6 \\
\hline Total & $\mathbf{0}$ & 4 & 3 & 5 & 32 & 39 & 9 & $\mathbf{0}$ & $\mathbf{0}$ & $\mathbf{0}$ & 17 & 4 & 22 & 10 & 145 \\
\hline
\end{tabular}

Table 2. Adults of saproxylophagous Melolonthidae sampled in a forest area in Aquidauana, MS, from March 2011 to February 2012.

\begin{tabular}{|c|c|c|c|c|c|c|c|c|c|c|c|c|c|}
\hline Subfamily/Species & Mar & Apr & May & June & July & Aug & Sept & Oct & Nov & Dec & Jan & Feb & Total \\
\hline \multicolumn{14}{|l|}{ Dynastinae } \\
\hline Phileurus valgus & & 1 & & & & & & & & & 1 & & 2 \\
\hline Pelidnota fulva & & & & & & & & 2 & & & & & 2 \\
\hline \multicolumn{14}{|l|}{ Rutelinae } \\
\hline Pelidnota aff. vazdemeloi & & & 1 & & 1 & 1 & & & & & & & 3 \\
\hline Macraspis festiva & & & & & & & & & 1 & & & & 1 \\
\hline \multicolumn{14}{|l|}{ Cetoniinae } \\
\hline Hoplopyga boliviensis & & & & & 1 & & 1 & & & & & & 2 \\
\hline Hoplopyga liturata & & & & & 1 & & & & & & & & 1 \\
\hline Total & $\mathbf{0}$ & 1 & 1 & 0 & 3 & 1 & 1 & 2 & 1 & $\mathbf{0}$ & 1 & 0 & 11 \\
\hline
\end{tabular}

adult hood. They remained for 230 days in the third instar, presented head capsule measuring $9.9 \mathrm{~mm}$ in width, and measured $62.8 \mathrm{~mm}$ long by $13.0 \mathrm{~mm}$ in thorax width (Table 3). Upon reaching the prepupal phase, they presented a reduced body length and constructed the pupal chamber, where they transformed into pupae and remained until emerging as adults (Figure 2). The pupal stage lasted for 31.3 days, where beetles measured $39.6 \mathrm{~cm}$ long by $20.2 \mathrm{~cm}$ wide at the thorax (Table 3). Adults emerged in October and November.

\section{Phileurus valgus}

In April 2011 four third instar larvae and one adult were obtained, in January 2012 another adult was sampled, and in April 2012 five third instar larvae were collected (Tables 1,2). Within the trunk of the wood sampled, which measured approximately $2 \mathrm{~m}$ long and $0.3 \mathrm{~m}$ in diameter, larvae remained on wood dust which was probably their feeding substrate and there was a large number of larvae excretions present. The excretions were cylindrical, dark and opaque. Third instar larvae presented a head capsule width of $6.3 \mathrm{~mm}, 64.1 \mathrm{~mm}$ in length and $9.2 \mathrm{~mm}$ in thorax width. The larvae remained for 49 days in the third instar before reaching the pupal stage (Table 3 ).

Within the rearing containers maintained in the laboratory, the larvae produced a pupal chamber with feces, saliva and material from the environment (organic material and soil). The pupal stage lasted 13 days, and after this period the adults emerged. Upon reaching adult hood, they remain within the pupal chamber for 11 days, probably waiting for the right conditions for flight. Pupae measured $22.2 \mathrm{~mm}$ long and $11.3 \mathrm{~mm}$ wide at the thorax (Table 3 ).
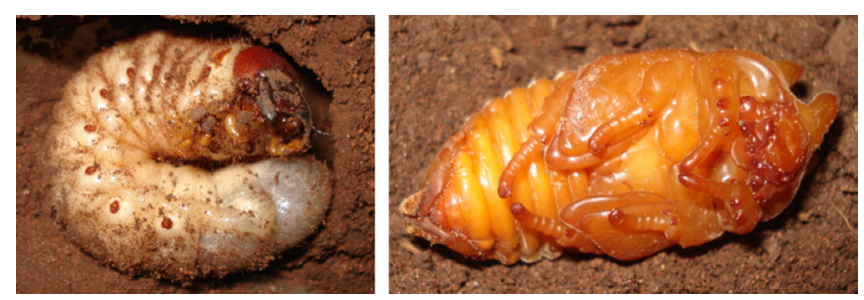

Figure 2. Third instar larvae and pupae of Strategus surinamensis, in Aquidauana, MS, from March 2011 to April 2012.

\section{Rutelinae}

\section{Pelidnota fulva}

Five larvae were collected in June and one in July 2011, which presented a head capsule width of $7.9 \mathrm{~mm}$, body length of $54.5 \mathrm{~mm}$ and thorax width of $11.5 \mathrm{~mm}$. In the laboratory the larvae phase lasted 61 days and the pupal phase 25.3 days, later reaching adult hood (Table 3).

\section{Pelidnota aff. vazdemeloi}

Three adults of $P$. aff. vazdemeloi were found in the months of May, July and August in the trunks of fallen trees (Table 2). Adults of Pelidnota aff. vazdemeloi (Figure 3) were in small chambers with average dimensions of $14.7 \mathrm{~mm}$ in width and $24.6 \mathrm{~mm}$ in length, probably waiting for appropriate conditions for leaving the tree 
Saproxylophagous Melolonthidae

Table 3. Biometric and biological data of saproxylophagous Scarabaeidae sampled in a forest area in Aquidauana, MS, from March 2011 to April 2012.

\begin{tabular}{|c|c|c|c|c|c|}
\hline Subfamily/Species & Phase & Duration (days) & Head capsule $(\mathrm{mm})$ & Length (mm) & Width (mm) \\
\hline \multicolumn{6}{|l|}{ Dynastinae } \\
\hline \multirow[t]{2}{*}{ Strategus surinamensis } & 3 instar & $230(210-240)$ & $9.9(9.3-10.8)$ & $62.8(46-82)$ & $13.0(9.4-14.6)$ \\
\hline & Pupa & $31.3(30-32)$ & - & $39.6(35.9-46.6)$ & $20.2(17.3-22.1)$ \\
\hline \multirow[t]{2}{*}{ Phileurus valgus } & 3 instar & 49 & 6.3 & 64.1 & 9.2 \\
\hline & Pupa & $13(12-15)$ & - & 22.2 & 11.3 \\
\hline \multicolumn{6}{|l|}{ Rutelinae } \\
\hline \multirow{3}{*}{ Pelidnota fulva } & 3 instar & 61 & 7.9 & 54.5 & 11.5 \\
\hline & Pupa & 25.3 & & & \\
\hline & Adulto & - & - & 22.5 & 12.7 \\
\hline Pelidnota aff. vazdemeloi & Adulto & & & 19 & 10.3 \\
\hline \multirow[t]{2}{*}{ Macraspis festiva } & 3 instar & $39(27-61)$ & $7.3(5.86-8.33)$ & $54.0(44.86-60.5)$ & $11.1(8.44-12.33)$ \\
\hline & Pupa & 17 & & 38.2 & 14.3 \\
\hline \multirow[t]{2}{*}{ Rutela lineola } & 3 instar & 23 & $5.5(4.98-5.97)$ & $42.1(37.67-47.5)$ & $7.8(6.25-8.28)$ \\
\hline & Pupa & 16.3 & & & \\
\hline \multicolumn{6}{|l|}{ Cetoniinae } \\
\hline \multirow[t]{3}{*}{ Hoplopyga boliviensis } & 2 instar & 12 & $2.1(1.8-2.6)$ & $11.6(10.8-12.9)$ & $3.2(2.9-3.6)$ \\
\hline & 3 instar & 33 & $3.3(2.8-4.10)$ & $25.2(22-28)$ & $6.3(4.9-7.1)$ \\
\hline & Pupa & $16(14-18)$ & & $13.7(12.7-14.9)$ & $8.7(8.1-10.1)$ \\
\hline \multirow[t]{2}{*}{ Hoplopyga liturata } & 3 instar & 21 & $2.9(2.5-3.30)$ & 26 & 6.8 \\
\hline & Pupa & 18 & & 12.1 & 5.3 \\
\hline \multirow[t]{3}{*}{ Marmarina maculosa } & 2 instar & 105 & 2.4 & 15.2 & 3.6 \\
\hline & 3 instar & $171.3(90-215)$ & $3.8(3.6-4.0)$ & $33.5(28.3-39.4)$ & $7.2(5.6-7.7)$ \\
\hline & pupa & $26(25-28)$ & & $17(16.5-18.0)$ & $9.4(8.7-10.6)$ \\
\hline
\end{tabular}

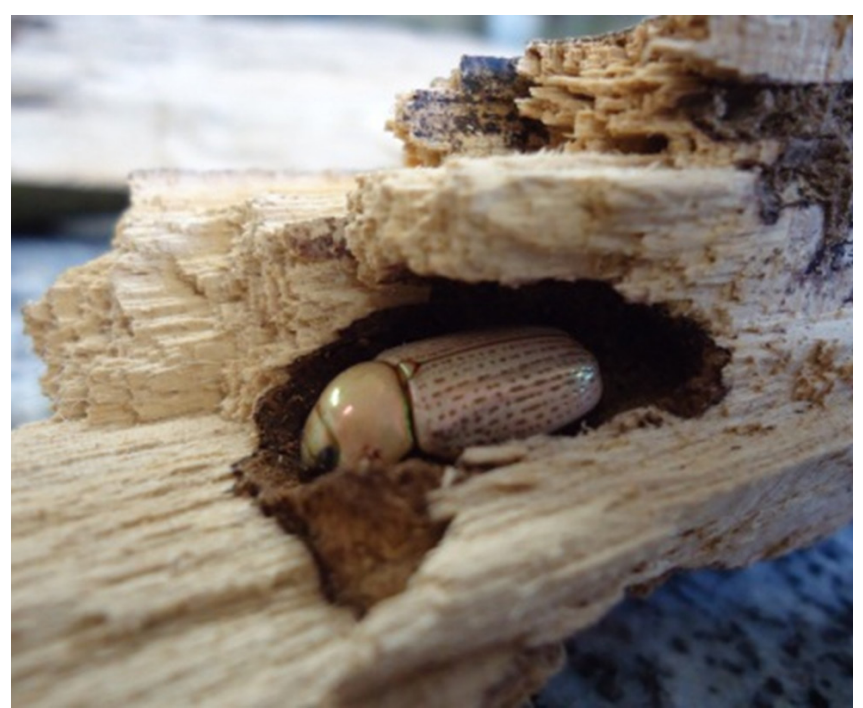

Figure 3. Adult of Pelidnota aff. vazdemeloi sampled within the pupal chamber, in a forest region, in Aquidauana, MS, from March 2011 to April 2012.

trunks. The adults collected measured $19.0 \mathrm{~mm}$ long by $10.3 \mathrm{~mm}$ wide (Table 3).

\section{Macraspis festiva}

In August 2011, 39 larvae were collected in the third instar, in November one adult was sampled, and in January, February, March and April of 2012, 17, 4, 12 and 3 third instar larvae were collected, respectively (Tables 1,2). Third instar larvae presented a head capsule wide of $7.3 \mathrm{~mm}$, length of $54.0 \mathrm{~mm}$ and thorax width of $11.1 \mathrm{~mm}$, and remained for 39 days in this development stage. Pupae measured $38.2 \mathrm{~mm}$ long, $14.3 \mathrm{~mm}$ wide at the thorax and this phase lasted 17 days (Table 3 ). In the laboratory adult mean longevity was 8.7 days. One adult was collected in a chamber inside a decaying tree trunk. The chamber measured $35 \mathrm{~mm}$ long by $19 \mathrm{~mm}$ wide.

\section{Rutela lineola}

Twenty larvae of $R$. lineola were collected in July, which were third instar larvae (Table 1), and of these ten reached adult hood. Third instar larvae had a head capsule width of $5.5 \mathrm{~mm}$, body length of 42.1 $\mathrm{mm}$ and a thorax width of $7.8 \mathrm{~mm}$ (Table 3). Larvae sampled in the field remained for 23 days on average in this stage. Upon reaching the pupal stage they remained for on average of 16.3 days in that phase, and then reached adult hood, staying alive in the rearing containers for 8.7 days. At the bottom of the rearing containers, larvae constructed a chamber where they reached the pupal stage. When the adult emerged it remained motionless in the pupal chamber for about three to four days, after this period they rose to the surface of the rearing container.

\section{Cetoniinae}

\section{Hoplopyga liturata}

One adult and two third instar larvae were collected in July (Tables 1,2). The larvae presented a head capsule width of $2.9 \mathrm{~mm}$, average length of $26 \mathrm{~mm}$ and thorax width of $6.8 \mathrm{~mm}$ (Tables 1-3). Larvae remained for 21 days in the third instar and then reached the pupal stage. The pupal stage lasted 18 days and the insects measured $12.1 \mathrm{~mm}$ long by $5.3 \mathrm{~mm}$ wide at the thorax (Table 3 ). When the larvae are about to turn into pupae, the pupal chamber is built with the material they feed on (decaying wood, dung and saliva). The pupal chamber is oval-shaped with mean dimensions of $18.3 \mathrm{~mm}$ long by $13.8 \mathrm{~mm}$ wide. When the adult emerges, it leaves the pupal 

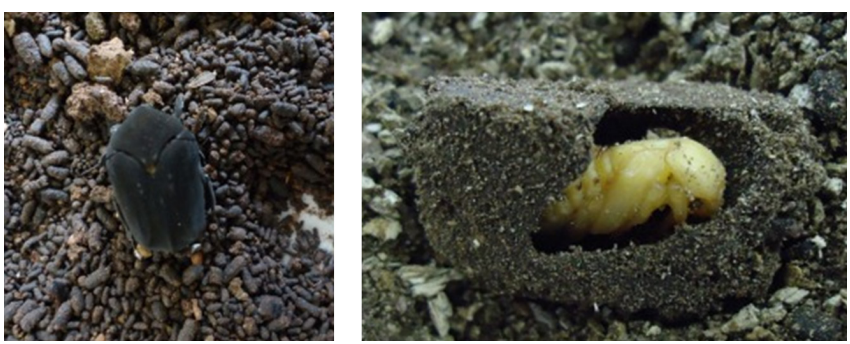

Figure 4. Adult (left) and pupa (right) of Hoplopyga boliviensis, collected in a forest area and reared in the laboratory, in Aquidauana, MS, from March 2011 to April 2012.

chamber by opening an oval hole in one extremity of the chamber with dimensions of $9 \mathrm{~mm}$ by $6 \mathrm{~mm}$.

\section{Hoplopyga boliviensis}

In samples collected from the tree trunks, one adult and nine third instar larvae were encountered in July, and one adult and nine larvae in September. The larvae collected in September, six were in the second instar and three were in the third instar (Tables 1,2).

The adult collected showed to be little sclerotized, probably because it recently emerged (Figure 4). Second instar larvae presented a head capsule width of $2.1 \mathrm{~mm}$, length of $11.6 \mathrm{~mm}$ and thorax width of $3.2 \mathrm{~mm}$ (Table 3). Third instar larvae had a head capsule width of $3.3 \mathrm{~mm}$, length of $25.2 \mathrm{~mm}$ and thorax width of $6.3 \mathrm{~mm}$. Larvae remained for 33 days on average in this stage until reaching the pupal stage (Table 3). Four larvae reached the pupal stage and they remained for 16.0 days in this stage. Pupae presented a length of $13.7 \mathrm{~mm}$ and thorax width of $8.7 \mathrm{~mm}$ (Table 3 and Figure 4). The larvae that are about to turn into pupae construct a pupal chamber with feeding material and saliva, where they remain sheltered until they reach adulthood. The pupal chamber has average dimensions of $17.8 \mathrm{~mm}$ long by $12.1 \mathrm{~mm}$ wide.

\section{Marmarina maculosa}

Six larvae were collected in March 2012, five third instar and one second instar larvae (Table 1). The second instar larva remained in this stage for 105 days, showed a head capsule width of $2.4 \mathrm{~mm}$, thorax width of $3.6 \mathrm{~mm}$ and body length of $15.2 \mathrm{~mm}$. The third instar larval phase lasted an average of 171.3 days, and these insects presented a head capsule width of $3.8 \mathrm{~mm}$, thorax width of $7.2 \mathrm{~mm}$ and body length of $33.5 \mathrm{~mm}$ (Table 2). Larvae reaching the pre-pupa phase constructed a chamber of decaying wood, dung and saliva, and remained there until adult emergence. The pupal chamber has external dimensions of $15.3 \times 22.2 \mathrm{~mm}$, and the pupae had a mean size of 9.4 $\times 17 \mathrm{~mm}$. The pupal duration was 26 days.

\section{Discussion}

For the region Aquidauana, MS, is recorded for the first time the relationship of nine species of Melolontidae saproxylophagous, which play an important role in recycling plant material. For some of the species collected there is some information in the literature which we present.

For the representatives of Dynastinae some information on biological aspects is known. The third instar larvae of S. surinamensis collected in Aquidauana, consumed a large amount of decaying wood, so it can be understood that this species plays an important consumer activity and decomposition of wood in the study area. The larvae showed maximum length of $82 \mathrm{~mm}$, and the pupae lasted 31.3 days on average. Costa et al. (1988) described the immature stages of Strategus surinamensis hirtus Sternberg, 1910, and reported that the third instar larvae measure about $150 \mathrm{~mm}$ in length, and upon reaching the pupal stage remain in this phase for 23 to 67 days. Thus, it appears that the larvae collected in Aquidauana, are smaller than those collected by Costa et al. (1988) but the pupal duration is similar. Although the genre Strategus, Morón (1985) reported that Strategus aloeus (L., 1758) plays an important role in the decomposition of wood in forests of Mexico. In the Brazilian state of Roraima, S. aloeus is reported as a pest to coconut palms (Pereira et al. 2004).

On P. valgus, Ratcliffe (2011) reviewed the genus Phileurus and reported that $P$. valgus occurs from the United States to Argentina and also in India. The third instar larva of $P$. valgus was described by Richter (1944). Morelli (1990), while studying Phileurus affinis Burmeister, 1847 in Uruguay, found that third instar larvae have a length of $65 \mathrm{~mm}$ and pupae measure $36 \mathrm{~mm}$ in length. Third instar larvae construct galleries in the trunks of plants with a diameter equal to their body. Therefore, it appears that the larvae of $P$. valgus collected in Aquidauana present length and behavior similar to $P$. affinis.

According to Neita et al. (2006), adults of Phileurus didymus (L., 1758 ) are found in rotting logs and in termite colonies (Nasutitermes $\mathrm{sp)}$. The larvae present gregarious behavior, and near the larvae adult females are encountered providing maternal care. Were found in Aquidauana, some larvae of $P$. valgus near some adults within the decaying wood, however, it was found that adults were newly emerged in function of the little sclerotized in his body.

In Rutelinae, the biological aspects of $P$. fulva were described by Rodrigues \& Falco (2011), who after obtaining adults induced their mating in decomposing material in the laboratory, and observed that the cycle from egg to adult is completed in 309.3 days and adult longevity was 12.08 days. The third instar larvae of $P$. fulva were described by Rodrigues et al. (2012). Larvae of Pelidnota chiriquina Bates, 1904 were collected in decaying logs in Colombia by Neita et al. (2006). Thus, it was noted that representatives of Pelidnota comprise an important group that aids in the decomposition of plant material. This is the first occurrence of adults of $P$. vazdemeloi in Mato Grosso do Sul developing in decaying wood.

Several larvae of M. festiva were collected in Aquidauana, and some studies in this genre have been developed. Morón \& PaucarCabrera (2003) studied larvae, pupae and adults of $M$. festiva in the Brazilian state of Amazonas, collected in rotting logs of Pachira sp. (Bombacaceae), where they obtained some information about the behavior, characterizing the species as saprophagous. Besides $M$. festiva, immature species were described for Macraspis aterrima Waterhouse, 1881, Macraspis rufonitida Burmeister, 1844, Macraspis chrysis (Linné, 1764) and Macraspis pseudochrysis Landin, 1956, and in all these species the larvae presented a xylophagous feeding behavior. Monné (1969) collected third instar larvae of Macraspis dichroa cribrata Waterh., 1881 in decaying tree trunks, from which the larvae were described. Vanin \& Costa (1980) collected Macraspis cincta larvae from decaying tree trunks, from which they reared and described the third instar larvae. When obtaining pupae they found that the duration of this phase was 19 days. As observed, the various representatives of Macraspis perform important decomposition activity of plant material, and in Aquidauana, MS, Brazil, $M$. festiva was the most abundant species with greatest quantity of sampled larvae.

The immatures of $R$. lineola were collected in large quantities in Aquidauana, comprising an important species that aids in the removal and decomposition of woods in the area of transition between the Cerrado and Pantanal, and some information of this species are known. Larvae of Rutela lineola, according to Calisto \& Morelli (2011), present a xylophagous feeding behavior and therefore they 
are normally found in fallen logs; and from the larvae sampled, the authors performed a description of larvae and pupae of this species.

In Cetoniinae many species that occur are known by the various attractive colors displayed by adults, as demonstrated by Solís (2004) in his study on Melolonthidae attracted to fruit in Costa Rica. In the genus Hoplopyga the feeding habits of some species are known. Larvae of Hoplopyga albiventris (Gory and Percheron, 1833) were found in nests of Cornitermes sp. according to Vanin \& Costa (1984), and fed directly within the nest, leaving this place only when they reach adult hood since adults prefer to feed on flowers and fruits. Immature species of Hoplopyga singularis (Gory and Percheron, 1833) were described after being collected in termite nests (Micó et al. 2001). Larvae of Hoplopyga brasiliensis (Gory and Percheron, 1833) were collected from nests of the termite Cornitermes cumulans (Kollar, 1832) and H. singularis (Gory and Percheron, 1833) in nests of the termite Diversitermes diversimiles (Silvestri, 1901), where they fed and completed their biological cycle according to Puker et al. (2012). Thus, it appears that the immature Hoplopyga can develop in the nests of termites or in decaying wood.

Larvae of $H$. liturata sampled in decaying wood were recorded in Aquidauana, and second Morón (1995) recorded adults are occurring in Mexico, Belize, Guatemala, Nicaragua, Costa Rica, Panama, Venezuela, Argentina and Brazil. The immature stages of $H$. liturata were described by Morón \& Arce (2002). Larvae of H. boliviensis, were also collected in decaying wood, and this species is scarce information available, being first introduced biological data and biometric data of the immature stages.

Few larvae of M. maculosa were collected in decaying wood in Aquidauana, MS. Third instar larvae and pupae of M. maculosa were described by Morón \& Arce (2002), after collecting larvae from decaying wood in a forest area in the state of Veracruz, Mexico. Monné (1969) described third instar larvae of Marmarina tigrina (Gory \& Percheron, 1833) collected in the nest of Acromyrmex sp. in Uruguay. For Marmarina the species may develop on decaying wood or in ant nests.

\section{Conclusion}

It is recorded for the first time that nine species of wood decomposers of the Melolonthidae in Mato Grosso do Sul. The first time informations are presented on the biological and biometric aspects of Hoplopyga boliviensis and Pelidnota aff. vazdemeloi.

\section{Acknowledgements}

To the Coordenação de Aperfeiçoamento de Pessoal de Nível Superior (CAPES) for providing the master's scholarship to the first author. To the Fundação de Apoio ao Desenvolvimento do Ensino, Ciência e Tecnologia do Estado de Mato Grosso do Sul (FUNDECT) for the financial support.

\section{References}

CALISTO, V. \& MORELLI, E. 2011. Descripción de los estados inmaduros de Rutela lineola (Linneu, 1767) (Coleoptera: Melolonthidae: Rutelinae). Acta Zool. Mex. 27(1):67-76.

COSTA, C., VANIN, S.A. \& CASARI-CHEN, S.A. 1988. Larvas de Coleoptera do Brasil. Museu de Zoologia, Universidade de São Paulo, São Paulo, 282p.

LINK, D. 1979. Nota sobre Rutela lineola. Rev. Centro Ciênc. Rur. 9(1):25-27.
MICÓ, E., HALL, W.E. \& RATCLIFFE, B.C. 2001. Descriptions of the larvae of Hoplopyga singularis (Gory and Percheron) and Hologyminetis cinerea (Gory and Percheron) with a revised key to the larvae of new world Gymnetini (Coleoptera: Scarabaeidae: Cetoniinae). Coleop. Bull. 55(2):205-217. http://dx.doi.org/10.1649/0010-065X(2001)055[0205: DOTLOH]2.0.CO;2

MONNÉ, M.A. 1969. Descripción del último estádio larval de Macraspis dichroa cribrata Waterh., Blaesia atra Burm. y Marmarina tigrina (Gory \& Perch.) (Coleoptera, Scarabaeidae). Rev. Bras. Biol. 29(3):367-376.

MORELLI, E. 1990. Descripción de la larva y la pupa de Phileurus affinis Burmeister, 1847 (Coleoptera: Scarabaeidae: Dynastinae). Algunas observasiones sobre su biologia y clave para la identificación de las larvas de tres especies de Phileurini del Uruguay. Elytron. 4:75-81.

MORÓN, M.A. 1985. Los insectos degradadores, un factor poco estudiado en los bosques de México. Fol. Entomol. Mex. 65:131-137.

MORÓN, M.A. 1995. Fenología y hábitos de los Cetoniinae (Coleoptera: Melolonthidae) en la región de Xalapa-Coatepec, Veracruz, México. G. It. Ent. 7(40):317-332.

MORÓN, M.A. \& ARCE, R. 2002. Descriptions of the immature stages of five Mexican species of Gymnetini (Coleoptera: Scarabaeidae: Cetoniinae). Proc. Entomol. Soc. Washing. 104(4):1036-1054.

MORÓN, M.A. \& PAUCAR-CABRERA, A. 2003. Larvae and pupae of species of the genus Macraspis (Coleoptera: Scarabaeidae: Rutelinae: Rutelini). Can. Entom. 135(4):467-491. http://dx.doi.org/10.4039/ n02-091

NEITA, J.C., OROZCO, J. \& RATCLIFFE, B. 2006. Escarabajos (Scarabaeidae: Pleurosticti) de la selva baja del bosque pluvial "BP-T", Choco, Colômbia. Acta Zool. Mex. 22(2):1-32.

PEREIRA, P.R.V.S., NECHET, K.L., HALFELD-VIEIRA, B.A. \& MOURÃO JUNIOR, M. 2004. Ocorrência da broca-da-raiz-do-coqueiro Strategus aloeus (linnaeus, 1758) (Coleoptera: Scarabaeidae) em coqueirais comerciais no estado de Roraima. Embrapa, Roraima, 5p. Comunicado Técnico, n.16.

PUKER, A., LOPES-ANDRADE, C., ROSA, C.S. \& GROSSI, P.C. 2012. New Records of Termite Hosts for Two Species of Hoplopyga, with Notes on the Life Cycle of Hoplopyga brasiliensis (Coleoptera: Scarabaeidae: Cetoniinae). Ann. Entomol. Soc. Am. 105(6):872-878. http://dx.doi. org/10.1603/AN12068

RATCLIFFE, B.C. 2011. A review of the species of Phileurus Latreille (Coleoptera: Scarabaeidae: Dynastinae: Phileurini) with quadridentate protibia and description of a new species from Panamá. Coleop. Bull. 65(2):125-129. http://dx.doi.org/10.1649/072.065.0203

RICHTER, P.O. 1944. Dynastinae of North America with descriptions of the larvae and keys to genera and species (Coleoptera: Scarabaeidae). Ky. Agr. Exp. Stat. Bull. 467:5-56.

RODRIGUES, S.R. \& FALCO, J.S. 2011. Aspectos biológicos de Pelidnota fulva (Coleoptera Scarabaeidae). Biota Neotrop. 11(1):157-160. http:// www.biotaneotropica.org.br/v11n1/en/abstract?article+bn02311012011 ISSN 1676-0603

RODRIGUES, S.R., MORÓN, M.A. \& NOGUEIRA, G.A.L. 2012. Description of the third instar of Pelidnota fulva Blanchard, 1850 (Coleoptera: Scarabaeidae: Rutelinae). Coleop. Bull. 66(3):266-270. http://dx.doi.org/10.1649/072.066.0314

SOLÍS, A. 2004. Escarabajos fruteros de Costa Rica. Instituto Nacional de Biodiversidad. Santo Domingo de Heredia. 238p.

VANIN, S.A. \& COSTA, C. 1980. Larvae of Neotropical Coleoptera. III: Scarabaeidae, Rutelinae. Pap. Avulsos Zool. 33(17):275-282.

VANIN, S.A. \& COSTA, C. 1984. Larvae of Neotropical Coleoptera. IX: Scarabaeidae, Cetoniinae, Cymnetini. Rev. Bras. Ent. 28(3):329-335.

VANIN, S.A., COSTA, C. \& FONTES, L.R. 1983. Larvae of Neotropical Coleoptera. VI. Scarabaeidae, Dynastinae, Phileurini. Pap. Avulsos Zool. 35(5):55-72. 